
0

\title{
Epicellular coccidiosis in goldfish
}

\author{
Kálmán Molnár, Csaba Székely* \\ Institute for Veterinary Medical Research, Centre for Agricultural Research, HAS, POB 18, \\ 1581 Budapest, Hungary \\ - corresponding author
}

ABSTRACT: In a goldfish stock held in a pet fish pond, heavy coccidian infection, caused by an epicellularly developing Goussia species, appeared in April of three consecutive years. The shape and size of its oocysts resemble to an inadequately described species, Goussia carassiusaurati (Romero-Rodrigez, 1978). In histological sections, gamogonic and sporogonic stages infested mostly the second fifth of the intestine, where almost all epithelial cells became infected. Both gamonts and young oocysts occurred intracellularly but in extracytoplasmal position, seemingly outside the cells. Oocysts were shed unsporulated. Sphaeroid to ellipsoidal unsporulated oocysts measured $12.4 \times 13.5 \mu \mathrm{m}$ on average, but after $48 \mathrm{~h}$ sporulation in tap water they reached $16 \times 13 \mu \mathrm{m}$ oocyst size, in which the four elliptical sporocysts of $13 \times 5.4 \mu \mathrm{m}$ located loosely. The size of oocysts and sporocysts are smaller than those of the better known Goussia species, Goussia aurati (Hoffman, 1965).

KEY WORDS: Coccidiosis, Goussia, goldfish, epicellular location, seasonal development

\section{INTRODUCTION}

Coccidia of the Eimeria and Goussia genera are common parasites of fish inhabiting European natural waters and aquaculture farms. The genus Goussia was first described and separated from Eimeria by Labbé (1896). Epicellular development of a Goussia species, G. pigra, was first demonstrated by Léger \& Bory (1932). Dyková \& Lom (1981) created a new genus Epieimeria for epicellularly developing fish coccidia selecting Epieimeria anguillae (Léger et Hollande 1922) Dyková et Lom, 1981 as the type species and revitalized the genus Goussia Labbé. Molnár (1989) found seasonally developing coccidia of nodular and 
epicellular types in cyprinid fishes and described them as Goussia balatonica and $G$. pannonica, respectively. Molnár (2006) regarded four genera common in fish, Eimeria, Goussia, Crystalospora, Calyptospora as members of the Eimeriidae family. Several authors among them Upton (2012) and Duszynski et al. (2016) still regard Goussia as synonym of Eimeria. In recent papers (Molnár et al. 2012, Rosenthal et al. 2016) where molecular sequences of different fish coccidia were examined, it was, however documented that great differences exist among Eimeria and Goussia spp, more over within the members of Goussia at least four groups can clearly be differentiated. Among Goussia spp. collected from Hungarian fishes Rosenthal et al. (2016) found that molecular sequences of species with small oocysts developing dispersedly in the gut of their hosts throughout the year differ from sequences of species with large oocysts developing seasonally in nodules and epicellular sites. Great differences were also found between nodular and epicellular species. Species infecting the kidney composed the fourth group.

Four coccidian species have been reported from the gut of goldfish. Goussia aurati was described by Hoffman (1965) as Eimeria aurati from the gut of a goldfish shedding fecal casts with non- sporulated oocysts, which, once sporulated, measured 16-24 × 14-17 $\mu \mathrm{m}$ and containing elliptical sporocysts measuring $11-13 \times 6.5-8 \mu \mathrm{m}$. He found this species similar to Goussia subepithelialis (Moroff \& Fiebiger, 1906), the nodular coccidium of the common carp, which according to data given by Steinhagen et al. (1990) have similar sizes with round 17-19 $\mu \mathrm{m}$ oocysts and 12-14 $\times 3 \mu \mathrm{m}$ sporocysts. Romero-Rodriguez (1978) found a similar species, Goussia carassiusaurati (described as Eimeria) in goldfish with $15.2 \times 13.3 \mu \mathrm{m}$ oocysts and $13.6 \times 5.8 \mu \mathrm{m}$ sporocysts. The third species Goussia hupehensis described by Chen \& Hsieh (1964) as Eimeria hupehensis is a typical dispersed coccidium resembling closely in its morphology Goussia carpelli (Léger et Stankovitch, 1921). G. hupehensis (Chen \& Hsieh, 1964) cit. by Chen \& Li (1973) was found also in Hungary by Molnár et al. (2005) who experimentally proved that this species (named only as Goussia sp.) cannot be transmitted to the common carp. A fourth species, described as Eimeria newchongensis by Chen (1984) from the gut of the goldfish and Culter erythropterus in China, by its $17.3-20 \mu \mathrm{m}$ sporulated oocysts, may not differ from G. auratii.

Here, we describe a coccidiosis in the gut of goldfish caused by epicellularly developing coccidian stages. 


\section{MATERIALS AND METHODS.}

Goldfish (Carassius auratus gibelio (L) are frequently cultured in small hobby ponds in Hungary, as well as in aquaria. From one of these ponds where about 100 specimens of 1 to 5 years old goldfish and their about 1000 offspring was cultured some fish were sent to laboratory for health control at about in monthly intervals. Fish were collected from the pond by a hand net, carried to the laboratory alive in oxygenated plastic bags, kept in aerated aquaria. They were sedated with $20 \mathrm{ppm}$ clove oil added to the water and exterminated by cutting their head. Coccidian infection of varying intensity with small sized oocysts of the dispersed G. hupehensis species was recorded throughout the examination period. In addition in Aprils of three consecutive years heavy infection with large sized oocysts resembling epicellular and nodular coccidia, common at this time in natural water fishes (Molnár 1989), were recorded. In April, 2016 a specific survey for coccidian infections was performed on twenty five specimens of 1 to 3 years old goldfish specimens measuring 4 to $13 \mathrm{~cm}$. The gut was opened lengthwise under a dissecting microscope and cut into five equal parts. From the epithelial surface, pieces of clean mucus were removed, placed under coverslip, and studied with a Nomarski differential interference contrast with an Olympus BH2 microscope. Some nonsporulated oocysts were placed in tap water into a small Petri dish and left to sporulate for 48 hours. Histological sections were prepared in 2016. In April 5, 15, and 25 the gut of the smallest fish, about $4 \mathrm{~cm}$ in length, was separated and coiled into a roll, fixed in Bouin's solution for four hours, embedded in paraffin wax, cut to 4-5 $\mu \mathrm{m}$ sections, and stained by haematoxylin and eosin. Non-sporulated and sporulated oocysts were studied using Nomarski differential interference contrast with an Olympus $\mathrm{BH} 2$ microscope. The oocysts and histological sections were photographed with an Olympus DP 20 digital camera. From oocysts digitised images were obtained and measurements were taken with the IMAGO ${ }^{\circledR}$ software. 


\section{RESULTS}

Heavy infections with non-sporulated oocysts were found in April in each year. At this time the gut of these fish was empty or contained only very little faeces. The fish were in poor condition but no mortality was recorded. No mortality was recorded on such fish subsequently held in laboratory aquarium for about a month. All of the examined fish proved to be infected. When freshly dissected, the second and fifth sections of the intestine were found to be most heavily infected with gamogonic and sporogonic stages. Relatively little infection was recovered in the first and third sections of the gut. From the last two sections, only nonsporulated oocysts were recovered and these were located free in the lumen of the gut or in faces. Oocysts were shed unsporulated. Most of the unporulated oocysts had a granulated structure and spheroid or short ellipsoidal shape (Fig. 1). In the first half of April, mostly developing gamonts were found in the first part of the intestine (Fig. 2). In the middle of April only non-sporulated oocysts were found in infected sections of the gut. By the end of April most oocysts had left the gut and only sparse oocysts were found in the rectum among faces. In tap water at $22-23{ }^{\circ} \mathrm{C}$, non-sporulated oocysts became sporulated in two days. Sporulated oocysts had also spheroid or short ellipsoidal shape (Fig. 3), a very thin, single layered and colourless wall. The oocysts (Table 1) measured $12.4 \pm 0.86(12.8-15.2) \mu \mathrm{m}$ in length and $13.5 \pm 1.8(12-14.6) \mu \mathrm{m}$ in width. There was no oocyst residuum, but a small polar body existed in oocysts. The four thin-walled, elongated ellipsoidal sporocysts located loosely in the oocysts, measured $13 \pm 0.8$ (11.2-15.4) $\mu \mathrm{m}$ in length and 5.4 \pm 0.34 (4.5-5.6) $\mu \mathrm{m}$ in width. In each sporocyst there were two vermiform sporozoites arranged head to tail. Sporozoites measured $10.3 \pm 0.73$ (9.6-11.2) $\mu \mathrm{m}$ in length and $2.5 \pm 0.32$ (2.4-2.8) $\mu \mathrm{m}$ in width. In freshly sporulated sporocysts, the sporocyst residuum covered most parts of the sporozoites, after 48 hours sporulation, this residuum became short and ellipsoidal, an about $2.5 \times 1.3$ compact body, and it located in the sporocysts among sporozoites.

In histological preparations fixed in the first half of April, heavy infection with young gamogonic stages was found in the second and third fifths of the intestine, while developing 
120

121

122

123

124

125

126

127

128

129

130

131

132

133

134

135

136

137

138

139

140

141

142

143

144

145

146

147

148

149

150

oocysts were only rarely found in the first fifth, and they were not found in the fourth and fifth segments of the gut. At this time, most of the gamonts were young, measuring about five $\mu \mathrm{m}$ in diameter. In some segments of the intestine, they infected almost every epithelial cell (Fig. 4). Less frequently, microgamonts were also found (Fig. 5). Development of gamogonic and sporogonic stages was not synchronous, as mature, unsporulated oocysts were found among developing gamonts (Fig. 6).

\section{DISCUSSION}

Although the genus Goussia is still regarded by many authors synonym to Eimeria (Upton 1912, Duszynski et al. 2016), others working on eimerians of fish and anurans accept its validity (Lukeš \& Dyková 1990, Steinhagen et al. 1990, Lukeš 1992, Jirkú et al. 2002, 2009, Dogga et al. 2015). Recent phylogenetic works (Molnár et al. 2012, Rosenthal et al. 2016) have validated deep evolutionary distinctions among the coccidian parasites of fish, including (but not limited to) a monophyletic assemblage limited to true members of the genus Eimeria; subdivisions within Goussia correspond to morphological and developmental attributes that likely warrant further taxonomic revision. Several Goussia species develop in nodules in the gut like G. subepithelialis, while others develop in epicellular position in the enterocytes like G. pigra. Molnár (1989) who described G. balatonica and G. pannonica spp. from the white bream, remarked that in several cyprinids a mixed infection with nodular and epicellular type coccidia occur in the time of oocyst formation in April. Morphologically similar oocysts which, however, differ in size also occur in non-cyprinids; these include Goussia aculeati, and G. zarnowskii in Gasterosteus aculeatus (L.) and G. acipenseris and G. vargai in Acipenser ruthenus (L.) (Jastrzebski 1984, Molnár 1986). It is not excluded therefore, that epicellular and nodular coccidia exist concurrently also in the common carp and the goldfish. Both fish species is of Chinese origin which introduced only a smaller part of their parasite fauna to Europe. The smaller (in average $16 \mu \mathrm{m}$ ) oocyst size measured for samples of the goldfish in the present investigation resembles to epicellular G. pannonica studied by Molnár (1989), and G. janae described by Lukeš \& Dyková (1990), while G. aurati, with its $16 \times 20$ $\mu \mathrm{m}$ large oocysts described by Hoffman (1965), correspond better to a nodular species. Although the above facts might suggest the nodular nature of $G$. aurati and the epicellular nature of $G$. carassiusaurati present data give not enough basis for drawing this conclusion. 
151 Similar problems exist at the common carp. To date, only a nodular species, $G$.

152 subepithelialis, has been reported from this fish. It cannot be ruled out, however, that a more

153 detailed examination in China, in the original biotope of the common carp and the gold fish

154 both nodular and epicellular species could be recorded.

155 Epicellular development characterizes a particular lineage of coccidia, which adds weight to 156 the validity of the genus Epieimeria Dyková \& Lom, 1981. On the other hand, the great 157 difference in morphology, development and molecular sequences between Goussia type 158 epicellularly developing coccidia and the type specimen Epieimeria anguillae contradicts a 159 relationship between the two eimerian groups. Differences in the development (permanently 160 developing group vice versa annually developing groups), intracellular location 161 (intracytoplasmal and epicytoplasmal), more over differences in the molecular sequences 162 among dispersed, nodularly and epicellularly developing groups (Rosenthal et al. 2016) would 163 favour creation of new coccidian genera in the future, among them a genus with a tentative 164 name Epigoussia.

165

166

167

168

Acknowledgements The authors thank G. Pataki for the preparation of histological slides. The authors are also thankful to dr. Yang Liu (College of Fisheries, Huazhong University, Wuhan, China) who helped the authors to the Chinese separates. Dr. Benjamin Rosenthal's suggestions and help in correcting the English of the manuscript are also greatly appreciated.

This study was financially supported by the by the Hungarian Scientific Research Fund (OTKA, project No. 100132) and by GINOP 2-3-2-15-2016-00004 project.

Compliance with ethical standards

Conflict of interest

The authors declare that they have no conflict of interest.

Ethical approval All applicable institutional, national and international guidelines for the care and use of animals were followed. Permit for scientific fishing in Hungary (EHVF/121-1/ 2014) is issued by the Ministry of Agriculture, Hungary.

Chen, CL (1984) Sporozoa of fishes from Liao He (Liaoho River) of China. In: Parasitic Organisms of Freshwater Fish of China, Edited by the Institute of Hydrobiology Academia Sinica, Agricultural Publishing House, Beijing. pp. 3-21.

Chen CL, Li, WW (1973) An Illustrated Guide to the Fish Disease and Causative Pathogenic Fauna and Flora in the Hupei Province. Publishing House Science, Institute of Hydrobiology, Wuhan, China. 456 pp. 
189

190

191

192

193

194

195

196

197

198

199

200

201

202

203

204

205

206

207

208

209

210

211

212

213

214

215

216

217

218

219

220

221

222

Dogga, SK, Bartosova-Sojkova P, Lukes J, Soldati-Favre D (2015) Phylogeny, Morphology, and Metabolic and Invasive Capabilities of Epicellular Fish Coccidium Goussia janae. PROTIST 166:659-676.

Duszynski DW, Couch L, Upton SJ (2016) Coccidia of the World. Available at: http://biology.unm.edu/biology/coccidia/home.html

Dyková I, Lom J (1981) Fish coccidia: critical notes on life cycle, classification and pathogenicity. J Fish Dis 4:487-505.

Hoffman GL (1965) Eimeria aurati n. sp. (Protozoa: Eimeriidae) from Goldfish (Carassius auratus) in North America. J Protozool 12:273-275.

Jastrzebski M (1984) Coccidiofauna of cultured and feral fishes in farms. Wiadomosci Parazytologiczne 30:144-160.

Jirkú M, Jirkú M, Obornik M, Lukeš J, Modry D (2009) Goussia Labbé, 1896 (Apicomplexa, Eimeriorina) in Amphibia: Diversity, Biology, Molecular Phylogeny and Comments on the Status of the Genus Protist 160:123-136.

Jirkú M, Modry D, Slapeta JR, Koudela B, Lukeš J (2002 The phylogeny of Goussia and Choleoeimeria (Apicomplexa; Eimeriorina) and the evolution of excystation structures in coccidia. Protist 153:379-390.

Labbé A (1896) Recherches Zoologiques, Cytologiques et Biologiques sur les Coccidies. Arch Zool Exp Gen 4:517-654.

Léger L, Bory T, (1932) Eimeria pigra n. sp. nouvelle coccidie juxtaépitheliale parasite du gardon rouge. C R Hebd Séanc Acad Sci 194:1710-1712.

Lukeš J (1992) Life cycle of Goussia pannonica (Molnár, 1989) (Apicomplexa, Eimeriorina), An extracytoplasmic coccidium from the white bream Blicca bjoerkna J Protozool 39:484-494.

Lukeš J, Dyková I (1990) Goussia janae n-sp (Apicomplexa, Eimeriorina) in dace Leuciscus leuciscus and chub Leuciscus cephalus. Dis Aquat Org 8:85-90.

Molnár K (1986) Occurrence of two new Goussia species in the intestine of the sterlet (Acipenser ruthenus). Acta Vet Hung 34:169-174.

Molnár K (1989) Nodular and epicellular coccidiosis in the intestine of cyprinid fishes. Dis Aquat Org 7:1-12.

Molnár K (2006) Phylum Apicomplexa. In: P.T.K. Woo (ed.): Fish Diseases and Disorders. Vol. 1: Protozoan and Metazoan Infections. Second edition. CAB International. Wallingford. pp. 183-204.

Molnár K, Ostoros Gy, Baska F (2005) Cross-infection experiments confirm the host 
specificity of Goussia spp. (Eimeriidae: Apicomplexa) parasitizing cypridid fish. Acta Protozool 44: 43-49.

Molnár K, Ostoros Gy, Dunams-Morel D, Rosenthal BM (2012) Eimeria that infect fish are diverse and are related to, but distinct from, those that infect terrestrial vertebrates. Infect Gen Evol 12:1810-1815.

Romero-Rodrigez J (1978) Coccidiopatias de peces, estudio del Protozoa Eimeriidae: Eimeria carassiusaurati, n. sp. Rev Iber Parasitol 38:775-781.

Rosenthal BM, Dunams-Morel D, Ostoros Gy, Molnár K (2016) Coccidian parasites of fish encompass profound phylogenetic diversity and gave rise to each of the major parasitic groups in terrestrial vertebrates. Infect Gen Evol 40: 219-227.

Upton SJ (2012) Suborder Eimeriorina Léger, 1911. In: Lee, J.J., Leedale, G.F., Bradbury, P. (Eds.), The Illustrated Guide to the Protozoa, second ed. Soc Protozoolog, Laurence, Kansas, pp. 318-339.

Steinhagen D, Lukeš J, Körting W (1990) Ultrastructural observations on gamogonic stages of Goussia subepithelialis (Apicomplexa, Coccidia) from common carp Cyprinus carpio. Dis Aquat Org 9:31-36.

\section{List of figures:}

Fig. 1. Non-sporulated Goussia oocysts shead by a goldfish. Bar=10 $\mu \mathrm{m}$

Fig. 2. Young gamogonic Goussia stages in a scraping of the intestinal epithelium. Bar=20 $\mu \mathrm{m}$

Fig. 3. Sporulated Goussia oocysts with round sporocysts and sporozoites (arrows). Bar=10 $\mu \mathrm{m}$

Fig. 4. Histological section of the second fifth segment of the gut. Young Goussia gamonts in epicellular position (arrows). Haematoxylin and eosin staining. Bar=20 $\mu \mathrm{m}$

Fig. 5. Micro- (arrows) and macro- Goussia gamonts (open arrows ) locating epicellularly in the intestine of a goldfish. Haematoxylin and eosin staining. Bar $=10 \mu \mathrm{m}$

Fig. 6. Asynchronous Goussia development in the intestine of the goldfish. Oocysts (open arrow) and young gamogonic stages (arrows) occur in the same time. Haematoxylin and eosin staining. Bar=20 $\mu \mathrm{m}$ 